\title{
Effects of nitrogen fertilization and protein supplementation on dairy cow nutrition at grazing
}

\author{
JL Peyraud, R Delagarde, L Delaby \\ INRA, Station de Recherches sur la Vache Laitière, 35590 St-Gilles, France
}

This trial studied the effects of lowering $N$ fertilization and of feeding a protein rich concentrate on intake and digestion in grazing dairy cows.

Two levels of $N$ fertilisation (Low $N(0)$, High $N$ $(60 \mathrm{~kg} \mathrm{~N} / \mathrm{ha} /$ growth)), and two levels of soyabean meal (SBM) supplementation (0 or 2 $\mathrm{kg} / \mathrm{cow} / \mathrm{d}$ included $1 \mathrm{~kg}$ of protected SBM) were compared in a $4 \times 4$ latin square design using eight fistulated dairy cows in mid lactation. Fertilization levels were applied on perennial ryegrass swards over 2 years. The swards were strip-grazed in Spring 1993 at a daily herbage allowance of $21 \mathrm{~kg} \mathrm{OM} / \mathrm{cow} / \mathrm{d}$ (above $5 \mathrm{~cm}$ ). Each period lasted 11 days. Herbage organic matter intake (HOMI) was estimated as described by Peyraud et al (this issue). Eight duodenal digesta samples were collected and the flow was calculated using chromic oxide and PEG concentrations in the whole digesta. Cows were dosed with markers at each milking time. Grazing time was automatically recorded. Urinary $\mathrm{N}$ was calculated by substracting milk and faecal $\mathrm{N}$ output from intake assuming no $\mathrm{N}$ retention.

Lowering $\mathrm{N}$ fertilization depressed HOMI, total digestible organic matter intake (DOMI) and milk yield. DOMI digestion sites were not affected. Grazing time $(525 \mathrm{~min} / \mathrm{d})$ did not vary and the rate of intake should have been reduced in relation to the lower herbage mass in the $\mathrm{LN}$ sward ( $1.9 \mathrm{vs} 2.6 \mathrm{tOM} / \mathrm{ha}$ ). In the $\mathrm{LN}$ sward, grass $N$ content was lowered (18.7 vs $30.8 \mathrm{~g} / \mathrm{kg} \mathrm{OM}$ ), the non ammonia nitrogen flow into the duodenum (NAN) was not modified $(28.6 \mathrm{~g} / \mathrm{kg} O M$ intake, $P>0.20)$ and largely exceeded $\mathrm{N}$ intake. Urinary $\mathrm{N}$ output was greatly lowered. However total NAN flow in $\mathrm{g} / \mathrm{d}$ was much lower in the LN sward than in the HN sward.

Feeding SBM increased total DOMI and daily NAN flow without affecting the sites of OM digestion. This agreed with the high response of milk yield (+ $1.4 \mathrm{~kg}$ milk $/ \mathrm{kg}$ SBM). HOMI and grazing time were not affected. This contrasted with the high substitution rate generally reported when feeding cereals to grazing cows (Meijs, 1986 in Grazing, Ed J Frame, BGS, occasional symposium, 19) and may be explained by the absence of rumen digestion disturbance due to the low level of SBM fed. There may also have been a stimulatory effect upon appetite of the higher amount of absorbed amino acids when feeding SBM. SBM supplementation increased urinary $\mathrm{N}$ flow but this flow was lower in LN2 than in the HNO treatment although DOMI, NAN flow and milk yield were quite similar.

Low $\mathrm{N}$ fertilization may greatly reduce energy and amino acid supply to the grazing cows. In this case, feeding SBM appears to be efficient to overcome the shortage of nutrients.

\begin{tabular}{|c|c|c|c|c|c|c|c|c|}
\hline & & & & & & & & \\
\hline & HNO & HN2 & LNO & LN2 & fer $\mathrm{N}$ & SBM & inter & rsd 1 \\
\hline milk production $(\mathrm{kg} / \mathrm{d})$ & 25.0 & 27.1 & 22.7 & 25.3 & $<0.01$ & $<0.01$ & 0.63 & 1.27 \\
\hline HOMI $(\mathrm{kg} / \mathrm{d})$ & 16.4 & 16.1 & 13.8 & 14.6 & $<0.01$ & 0.54 & 0.18 & 1.19 \\
\hline total DOMI $(\mathrm{kg} / \mathrm{d})$ & 13.3 & 14.4 & 10.8 & 12.9 & $<0.01$ & $<0.01$ & 0.20 & 1.00 \\
\hline $\begin{array}{l}\text { ruminal digestion (\% DOMI) } \\
\text { NAN flow }\end{array}$ & 69 & 68 & 70 & 69 & 0.68 & 0.43 & 0.98 & 4.9 \\
\hline$(g / d)$ & 472 & 570 & 394 & 518 & $<0.01$ & $<0.01$ & 0.54 & 60.1 \\
\hline$(\% N$ Intake $)$ & 77 & 77 & 121 & 108 & $<0.01$ & 0.09 & 0.08 & 9.9 \\
\hline Urinary $N$ output $(\mathrm{g} / \mathrm{d})$ & 380 & 472 & 130 & 242 & $<0.01$ & $<0.01$ & 0.91 & 31.9 \\
\hline
\end{tabular}

1 : residual standard deviation of the model 